\title{
Reasons for Volunteering in the Field of Civil Protection in Germany
}

\author{
${ }^{1}$ Ernst-Moritz-Arndt-University Greifswald, Institute of Psychology, Department Health and Prevention, Robert-Blum-Str. 13 , \\ 17487 Creifswald, Germany, Phone: +49 (0)3834 86-3810, Fax: +49 (0)3834 86-3801, E-mail: doris.kehl@uni-greifswald.de \\ ${ }^{2}$ University Medicine Greifswald, Institute of Medicine Psychology, Walther-Rathenau-Str. 48, 17475 Greifswald, Cermany, \\ E-mail: doris.kehl@uni-greifswald.de \\ ${ }^{3}$ Ernst-Moritz-Arndt-University Greifswald, Institute of Psychology, Department Health and Prevention, Robert-Blum-Str. 13, \\ 17487 Creifswald, Cermany
}

\begin{abstract}
:
This study investigates how the demographic characteristics (i.e. gender, age, immigrant status) of people volunteering for civil protection organizations, as well as the type of organization, influence the volunteers' motivation to provide this service. A sample of 3320 volunteers was drawn from the following non-profit civil protection organizations in Germany: a) Voluntary Fire Brigade, b) German Red Cross, and c) German Federal Agency for Technical Relief. Reasons for volunteering were assessed by the Scales of Attitude Structure of Volunteers. Correlation analyses, and ANOVAs were conducted. No effects of type of organization and immigrant status on reasons for volunteering were detected. Men's and women's reasons for doing voluntary service were equal, with one exception: self-experience motivation, i.e., the motivation to gain knowledge, skills etc., was higher among female volunteers. Age was negatively associated with social motivation, self-esteem, and career motivation. Our finding that gender and age affect volunteers' motivation can be used to improve recruitment advertisements in the future: the various age groups can be targeted according to their specific motives for doing voluntary service, and the result that self-experience is more important to women than it is to men could also be explored to enhance the recruitment of women.
\end{abstract}

Keywords: civil protection, emergency, motives, reasons, voluntary work, volunteers

DOI: $10.1515 /$ jhsem-2016-0042

\section{Background}

Although natural disasters such as floods, tsunamis, El Nino events, bush and forest fires, and famine have occurred throughout history, recent trend data indicate that they are increasing each year across the globe, with greater intensity, and that the overall number of affected people is rising (Coppola 2015). Also, the cost of disasters is rising worldwide (Coppola 2015). In these times of scarce financial resources, non-governmental (NGO) and non-profit organizations (NPO) are essential and should be significant partners of local, state and federal governments in responding to emergencies and disasters ( Haddow, Bullock, and Coppola 2014). However, the existence of these voluntary organizations and the scope of volunteer engagement in emergency management vary considerably from one country to another ( Alexander 2010; Q3: Please update the Ref. "Dostál and Balarinová (2013)”Dostál and Balarinová 2013). For example, the United States has a strong voluntary culture within emergency management, whereas South Korea has only recently established its voluntary agencies in emergency management ( Ha and Ahn 2008). The Chinese government has also recently recognized that government efforts alone are not sufficient to manage disasters and has encouraged the development of NGOs, although they still lack comprehensive disaster management skills and tools (Shanli 2014). In Japan, the East Japan Triple Disaster in 2011 - the 9.0 earthquake, followed by a massive tsunami and the meltdowns at the Fukushima nuclear plant - has led to an increase of NGOs/NPOs providing emergency aid ( Sakamoto 2012).

As in the United States, emergency and disaster management in Germany is based on a combination of professional personnel and volunteers affiliated with official organizations (i.e. formal volunteering). The three largest civil protection organizations in Germany are the voluntary fire brigade (VFB), the German Red Cross (GRC), and the German Federal Agency for Technical Relief, which is a unit of the German Home Office (German acronym: THW). About 1.8 million volunteers are trained to help in crisis management and civil protection ( Federal Office of Civil Protection and Disaster Assistance [Bundesamt für Bevölkerungsschutz und Katastrophenhilfe] 2015). However, the number of volunteers in each organization is steadily declining. An annual 
survey carried out by the German Fire Service Association (GFSA) to collect data about membership development has shown that the number of volunteer firefighters decreased from the year 2000 to 2013 (2000: 1.069.765; 2010: 1.036.745; and 2013: 1.008.133; German Fire Service Association [Deutscher Feuerwehrverband] 2016b). Likewise, the number of active volunteers of the GRC has dropped: from 286,475 in 2010 to 276,461 in 2015; as has the number of sponsoring members: from 3,495,044 in 2010 to 3,026,576 in 2015 ( Statista GmbH 2016). The THW has around 80,000 volunteers, about half of whom are active volunteers (German Federal Agency for Technical Relief [Technisches Hilfswerk] 2016b), but this number also shows a decline (from about 41,000 in 2010 to 39,000 in 2011; Klöpper 2012). On the other side, there are about 1000 THW paid staff members (German Federal Agency for Technical Relief [Technisches Hilfswerk] 2016b), approximately 158,000 GRC paid staff members ( German Fire Service Association [Deutscher Feuerwehrverband] 2016b), and approximately 30,500 professional firefighters employed in Germany ( German Fire Service Association [Deutscher Feuerwehrverband] 2016b).

The decreasing numbers of volunteers are likely to be due to demographic changes in Germany, i.e. the decline of the population size, aging of the society, and the shrinking number of young people. These trends will accelerate in the coming decades due to the existing age structure (Mai and Swiaczny 2008). Moreover, the proportion of people with an immigration background will also increase.

Moreover, research in Germany has shown that females, people aged 60 or above, and immigrants are minorities in the organizations of civil protection ( Hielscher and Nock 2014). About 41\% of GRC volunteers are women (Geenen 2012), but only 13\% of THW volunteers ( German Federal Agency for Technical Relief [Technisches Hilfswerk] 2016a), and 8.5\% (in 2013) of volunteer firefighters (German Fire Service Association [Deutscher Feuerwehrverband] 2016b). Regarding age, the fire service has an age limit for active volunteers of between 60 and 67 years, depending on federal state (German Fire Service Association [Deutscher Feuerwehrverband] 2016a). The THW has only recently eliminated the age limit of 60 years (in 2013) - volunteers are now divided into those with and without the capability to operate in emergency situations (German Federal Agency for Technical Relief [Technisches Hilfswerk] 2014). The GRC has no specific age limits (German Red Cross [Deutsches Rotes Kreuz] 2016). Regarding immigrants, data of a recent representative survey in Germany showed that only $2.1 \%$ of the 389 surveyed persons with an immigration background was a voluntary active member in the field of civil protection ( BIK 2013). Compared with the proportion of $21 \%$ of the population of Germany ( Federal Statistical Office [Statistisches Bundesamt] 2016), immigrants are significantly underrepresented as volunteers in the German civil protection. Those immigrants that are active volunteers in a civil protection organization mainly service the GRC (20.4\%) and VFB (19.4\%); only 6.4\% volunteered in the THW ( BIK 2013).

Because of the abovementioned demographic changes in Germany, the conditions for a successful volunteer recruitment have changed. This paper investigates the reasons why people join civil protection organizations and why they continue their volunteering work, taking into account the type of volunteer organization and key demographic features.

\section{Motives for Volunteering}

The functional motivation theory by Clary et al. (1998) states that people become and remain a volunteer as long as the volunteer activity meets their personal motivations, which could change over time (Clary and Snyder 1999). Reasons for volunteering can be altruistic (i.e. other-oriented) and/or egoistic (i.e. me-oriented) (Clary et al. 1998; Clary and Snyder 1999). While some models assume the existence of two motives, such as egoistic vs. altruistic motives (Frisch and Gerrard 1981), or intrinsic vs. extrinsic motives (Finkelstein 2009), one of the most widely accepted models of motivation (Widjaja 2010) is the multi-dimensional model of Clary et al. (1998). This model identifies six distinct motives, which are measurable with the Volunteer Functions Inventory (VFI): (1) to express one's altruistic and humanitarian values - desire to help; (2) to gain knowledge, skills, and abilities understanding motive; (3) to develop and strengthen social ties - social motive; (4) to improve career prospectscareer motive; (5) to develop and strengthen a person's self-esteem and self-importance - enhancement motive; and (6) to escape from own difficulties - protective motives. It has been argued that by addressing these primary motives of people, recruitment messages can persuade more people to take up voluntary work (Clary et al. 1998; 1994).

The research question of the present study is how the demographic characteristics (i.e. gender, age, immigrant status) of people volunteering for civil protection organizations, and the type of organization, influence the volunteers' motivation to provide this service. The answer is important because each organization should offer those tasks and positions that meet the motives of their potential volunteers (Clary and Snyder 1999). In the following, theoretical and empirical findings from previous studies are presented and five hypotheses regarding volunteers' motives and the type of organization are derived from them. 


\section{Type of Volunteer Organization in Civil Protection}

The GRC, VFB and THW rely on the cooperation of professional personnel and volunteers. The tasks in the three organizations are characterized by an emphasis on social responsibility. Although the activities are quite different, all three organizations depend on highly qualified and committed volunteers, in whom they invest substantial resources. Furthermore, all organizations have traditionally been apolitical. Therefore, the reasons for people doing voluntary service in these organizations can be expected to be similar in terms of the altruistic motive, understanding motive, and career motive; political motives probably do not play any role for volunteers. Recently collected data of 949 volunteers revealed that the three main reasons for volunteering - "to help others", "social contacts in the community interest me", and "friends have involved me" - were equal for the three organizations; political responsibility as a motivational factor was not mentioned by any of the volunteers ( BIK 2013). Thus, the following Hypothesis was derived:

Hypothesis 1: The voluntary members of Germany's three largest NPOs in civil protection (i.e. VFB, GRC, and THW) do not differ in their motives for conducting voluntary service.

\section{Gender}

Previous research has found that for both women and men, the most important reasons for volunteering are to help people and to gain knowledge, skills, and abilities (Chapman and Morley 1999; Fletcher and Major 2004; Yadessa 2015), whereas social, career, and protective motives seem to be less important (e.g. Okun and Schultz 2003). However, for women, it is more important to gain knowledge and skills than it is for men (Chapman and Morley 1999; Fletcher and Major 2004; Yadessa 2015). The social factor was rated equally by women and men ( Chapman and Morley 1999; Switzer et al. 1999; Fletcher and Major 2004; Yadessa 2015). There are no unambiguous study results with regard to the following motives: (i) helping other people, (ii) improving career prospects, (iii) developing self-esteem, and (iv) protecting the ego (Chapman and Morley 1999; Switzer et al. 1999; Fletcher and Major 2004; Yadessa 2015). Thus, our second hypothesis states:

Hypothesis 2: Some reasons for volunteering will be similar for men and women (e.g. social motivation), and some will be dissimilar, such as the motivation to gain knowledge and skills.

\section{Age}

Both younger and older volunteers have a high motivation to help other people (Francis and Jones 2012). However, younger volunteers have a higher career motivation and a greater desire to acquire knowledge and skills, compared to older people ( Omoto, Snyder, and Martino 2000; Francis and Jones 2012). In accordance, results of Okun and Schultz (2003) indicated that the career motivation and the motivation to gain knowledge and skills decreases with age. Findings regarding the effect of age on the social motive and on the motive of helping others have been varied ( Omoto, Snyder, and Martino 2000; Okun and Schultz 2003). Thus, Hypothesis 3 proposes:

Hypothesis 3: Age will be negatively associated with career motivation and the motivation to gain knowledge and skills.

It remains unclear whether the reasons of people entering a voluntary service differ from those of long-time volunteers. Frisch and Gerrard (1981) found that senior volunteers stated that the motivation to help others is higher now compared to when they started. Thus, the fourth hypothesis states:

Hypothesis 4: The motivations of people entering a voluntary service differ from those who have already volunteered for a longer time.

\section{Immigrant Status}

Second generation immigrants are more strongly influenced by the cultural values of the host country than immigrants of the first generation ( Schiefer 2013). Second generation immigrants adopt the values of the host country more easily, as they have already been exposed to these values throughout their lives (Hwang 2006). Recent immigrants have more employment-related reasons (e.g. improving job-related skills) for volunteering 
than immigrants who have already lived in the host country for more than 4 years, although the highest motivational reason for both groups was of social nature ( Handy and Greenspan 2009). Since training in the area of civil protection is difficult without adequate language skills, volunteers working in this field are assumed to have very good language skills and to be well-integrated into German society. Consequently, the motives of people with an immigrant background are assumed to be the same as those of non-immigrants. The last hypothesis therefore states:

Hypothesis 5: Reasons for volunteering will be similar across different groups of persons with different immigrant status.

Additionally, reasons why people terminate their voluntary work in the field of civil protection are also explored in this study.

\section{Methods}

\section{Sample}

A convenience sample of 3320 volunteers was drawn, involving volunteer members of the VFB ( $n=861)$, GRC $(n=1221)$ and THW $(n=1238)$. Although the survey was not limited to adults, as children and adolescents also do voluntary services, all participants were at least 14 years of age due to the guidelines for interviewing minors in Germany (see guidelines issued by the Work Group of the German Market and Social Research Institute e.V., Work Group of the Association of Social Science Institutes e.V., Association of German Market and Social Researchers e.V., German Society for Online e.V [Arbeitskreis Deutscher Markt - und Sozialforschungsinstitute e.V., Arbeitsgemeinschaft Sozialwissenschaftlicher Institute e.V., Berufsverband Deutscher Markt- und Sozialforscher e.V., Deutsche Gesellschaft für Online-Forschung e.V 2006). Nation-wide recruitment strategies included: top-down recruitment (i.e. staff intranets, displayed adverts for the project with a link to the online questionnaire), posts and links on social network web sites (e.g. Facebook, first responder forums), and presentations at conferences. The project web site (http:/ / www.inka-sicherheitsforschung.de/start/) also contained study information plus a link to the online study. Ethical approval was obtained from the ethics committee of the University of Greifswald, Germany.

\section{Instruments}

\section{Sociodemographic and Organization-related Information}

Participants answered questions regarding their demographic characteristics (e.g. gender, age, educational level, immigrant status). Immigrant background was assessed by the following characteristics: present and former citizenship of participant; present and former citizenship of participants' mother; present and former citizenship of participants' father ( Federal Statistical Office [Statistisches Bundesamt] 2015). Based on these data, the participants were assigned one of three immigrant statuses: non-immigrant, people with immigrant background but with the German citizenship and no other (previous) citizenship, and any other immigrant. Additionally, immigrants graded their self-perceived integration in Germany introduced by the following statement: "In the following, we would like to ask you about your situation in Germany." Participants used a 5-point Likert scale ( $1=$ not at all, and $5=$ extremely) to rate the following statements: "I feel at home in Germany", "I maintain social relations with Germans", and "I feel respected by Germans". Responses were added up to create a total mean score, and the coefficient alpha for the total score was 0.81 .

Additionally, all participants answered questions regarding the type of organization that they worked for, their years of service, and whether they had ever contemplated terminating their voluntary service by answering the question "Have you ever thought about ending your volunteer work in the field of crisis management and disaster recovery?". Seven different statements were used to assess reasons for termination (see Table 3).

\section{Scales of Attitude Structure of Volunteers}

Although in several studies the abovementioned VFI ( Clary et al. 1998) was used to investigate motives for voluntary service, in this study the German-language questionnaire Scales of Attitude Structure of Volunteers 
(German acronym: SEEH; Bierhoff, Schülken, and Hoof 2007) was used, because no German validated version of the VFI existed. Despite the different taxonomies of the SEEH and the VFI, considerable overlap can be found; nonetheless, there are few differences between the two models, which will be discussed briefly after the description of the SEEH. The questionnaire SEEH assessed the willingness of volunteers to contribute to an NPO. The questionnaire comprised 21 items assessing the following eight incentives and reasons for voluntary work: (1) to develop and strengthen social ties - social motivation; (2) to have new experiences and get to know oneself better/to know about one's strengths and weaknesses - self-experience motivation; (3) desire for self-fulfillment and to develop and strengthen one's self-esteem; (4) because of influence of family members or friends - social influence; (5) to balance professional work - work-life-balance; (6) to improve career prospects - career motive; (7) to help other people - social responsibility; and (8) to achieve political/social changes political responsibility. These eight scales were assigned to either the self-serving or the altruistic orientation dimension. The SEEH was introduced as follows: "Below you will find a number of possible reasons for volunteering in a non-profit organization. Please indicate for each of the listed reasons how important or unimportant this reason is for your current motivation to do volunteer work." The item response anchors ranged from $1=$ the cause is absolutely unimportant to 9=the cause is absolutely important. Bierhoff, Schülken, and Hoof (2007) confirmed the eight theoretically derived attitude dimensions with a factor analysis and documented construct validity of the scales.

There are a few differences between the VFI and SEEH, for example with respect to the protective reason ( Bierhoff, Schülken, and Hoof 2007). The issue of the VFI protective scale, which describes voluntary work as a relief from other difficulties, is addressed only indirectly in the work-balance scale, without explicitly formulating the psychological defense function as described in the items of the VFI protective scale, e.g. "Volunteering is a good escape from my own troubles" ( Bierhoff, Schülken, and Hoof 2007). Furthermore, SEEH addresses two topics which were not addressed in earlier analyses: social influence and political responsibility (Bierhoff, Schülken, and Hoof 2007).

\section{Data Analysis}

Data analysis was carried out using SPSS and descriptive statistics were calculated. Analyses of variance (ANOVA) and chi-square tests were run to establish whether demographic and work characteristics differed across the organizational samples (see Table 1). Differences between the samples were observed with regard to gender: $\chi^{2}(2)=88.54, p<0.001$, Cramer's V=0.16; number of years of volunteer service: $F(2,3268)=25.32, p<0.001$, $\eta=0.12$; and age of entry into service: $F(2,3268)=37.40, p<0.001, \eta=0.15$. No effects were observed regarding age, educational level, and immigrant status. Furthermore, zero-order correlations (Pearson), coefficient alphas, means, and standard deviations for scores on the SEEH were calculated (Table 2). ANOVAs were conducted to determine the effect of type of organization, gender, and immigrant status on SEEH scores. Correlation analyses were performed to reveal the effect of age on SEEH scores.

Table 1: Demographic and Working Characteristics Across Organizational Samples.

\begin{tabular}{|c|c|c|c|c|c|c|}
\hline & \multicolumn{2}{|c|}{ VFB $(n=861)$} & \multicolumn{2}{|c|}{ GRC $(n=1221)$} & \multicolumn{2}{|c|}{ THW ( $n=1238)$} \\
\hline & $\mathbf{n}$ & $\%^{a}$ & $\mathbf{n}$ & $\%^{a}$ & $\mathrm{n}$ & $\%^{a}$ \\
\hline Male & 785 & 91.2 & 950 & 77.8 & 1096 & 88.5 \\
\hline \multicolumn{7}{|l|}{$\operatorname{Age}^{\mathrm{b}}$} \\
\hline$<20$ years & 40 & 4.6 & 70 & 5.7 & 64 & 5.2 \\
\hline 20-39 years & 497 & 57.7 & 698 & 57.2 & 754 & 60.9 \\
\hline 40-59 years & 302 & 35.1 & 409 & 33.5 & 370 & 29.0 \\
\hline$>60$ years & 22 & 2.6 & 44 & 3.6 & 50 & 4.0 \\
\hline \multicolumn{7}{|l|}{ Education level } \\
\hline $\begin{array}{l}\text { Still going } \\
\text { to school }\end{array}$ & 3 & 0.3 & 23 & 1.9 & 13 & 1.1 \\
\hline $\begin{array}{l}\text { Lowest } \\
\text { formal }\end{array}$ & 89 & 10.3 & 141 & 11.5 & 129 & 10.4 \\
\hline $\begin{array}{l}\text { Intermedi- } \\
\text { ary } \\
\text { secondary }\end{array}$ & 259 & 30.1 & 374 & 30.6 & 357 & 28.8 \\
\hline Higher sec- & 510 & 59.2 & 683 & 56.0 & 739 & 59.7 \\
\hline
\end{tabular}

ondary/uni-

versity 


\begin{tabular}{|c|c|c|c|c|c|c|}
\hline \multirow{2}{*}{$\begin{array}{l}\text { Immigrant } \\
\text { background }^{\mathrm{e}}\end{array}$} & 50 & 5.9 & 112 & 9.3 & 96 & 7.9 \\
\hline & $\mathrm{M}$ & SD & $\mathrm{M}$ & SD & $\mathrm{M}$ & SD \\
\hline $\begin{array}{l}\text { Years of } \\
\text { service }^{c}\end{array}$ & 17.42 & 11.00 & 14.49 & 11.60 & 14.00 & 11.23 \\
\hline $\begin{array}{l}\text { Age of entry } \\
\text { into service }\end{array}$ & 18.61 & 6.44 & 21.65 & 8.70 & 21.38 & 9.37 \\
\hline
\end{tabular}

VFB, voluntary fire brigade; CRC, German Red Cross; THW, Cerman federal agency for technical relief; ${ }^{\mathrm{a}}$ valid percent; ${ }^{\mathrm{b}} \mathrm{M}=35.8, \mathrm{SD}=11.97$, Range: $14-76 ;{ }^{\mathrm{c}}$ range: O-59; ${ }^{\mathrm{d}}$ range: $6-67{ }^{\mathrm{e}}{ }^{\mathrm{e}}$ missing: $n=37$ (1.1\%).

Table 2: Zero-Order Correlations (Pearson), Coefficient Alphas, Means, and Standard Deviations for scores on the SEEH. ${ }^{a}$

\begin{tabular}{|c|c|c|c|c|c|c|c|c|c|c|}
\hline & 1 & 2 & 3 & 4 & 5 & 6 & 7 & 8 & I & II \\
\hline $\begin{array}{l}1 . \\
\text { SEEH: } \\
\text { social } \\
\text { ties }\end{array}$ & $(0.86)$ & & & & & & & & & \\
\hline $\begin{array}{l}2 . \\
\text { SEEH: } \\
\text { self- } \\
\text { experience }\end{array}$ & $0.427^{c}$ & $(0.83)$ & & & & & & & & \\
\hline $\begin{array}{l}3 . \\
\text { SEEH: } \\
\text { social } \\
\text { respon- } \\
\text { sibility }\end{array}$ & $0.223^{c}$ & $0.433^{c}$ & $(0.78)$ & & & & & & & \\
\hline $\begin{array}{l}4 . \\
\text { SEEH: } \\
\text { self- } \\
\text { esteem }\end{array}$ & $0.336^{c}$ & $0.292^{c}$ & $0.183^{c}$ & $(0.86)$ & & & & & & \\
\hline $\begin{array}{l}5 . \\
\text { SEEH: } \\
\text { social } \\
\text { influ- } \\
\text { ence }\end{array}$ & $0.270^{c}$ & $0.154^{c}$ & $0.151^{c}$ & $0.450^{c}$ & $(0.88)$ & & & & & \\
\hline $\begin{array}{l}6 . \\
\text { SEEH: } \\
\text { profes- } \\
\text { sional } \\
\text { balance }\end{array}$ & $0.247^{c}$ & $0.275^{c}$ & $0.196^{c}$ & $0.350^{c}$ & $0.324^{c}$ & $(0.75)$ & & & & \\
\hline $\begin{array}{l}7 . \\
\text { SEEH: } \\
\text { career }\end{array}$ & $0.273^{c}$ & $0.263^{c}$ & $0.122^{c}$ & $0.474^{\mathrm{c}}$ & $0.448^{c}$ & $0.395^{c}$ & $(0.79)$ & & & \\
\hline $\begin{array}{l}8 . \\
\text { SEEH: } \\
\text { politi- } \\
\text { cal } \\
\text { respon- } \\
\text { sibility }\end{array}$ & $0.212^{c}$ & $0.224^{c}$ & $0.203^{c}$ & $0.328^{c}$ & $0.425^{c}$ & $0.313^{c}$ & $0.544^{c}$ & $(0.87)$ & & \\
\hline $\begin{array}{l}\text { I SEEH: } \\
\text { self- } \\
\text { serving } \\
\text { orienta- } \\
\text { tion }\end{array}$ & $0.637^{c}$ & $0.595^{c}$ & $0.335^{c}$ & $0.746^{c}$ & $0.643^{c}$ & $0.639^{c}$ & $0.731^{c}$ & $0.519^{c}$ & $(0.88)$ & \\
\hline $\begin{array}{l}\text { II } \\
\text { SEEH: } \\
\text { altruis- } \\
\text { tic } \\
\text { orienta- } \\
\text { tion }\end{array}$ & $0.250^{c}$ & $0.421^{c}$ & $0.706^{c}$ & $0.332^{c}$ & $0.314^{\mathrm{c}}$ & $0.293^{c}$ & $0.437^{c}$ & $0.497^{c}$ & $0.515^{c}$ & $(0.78)$ \\
\hline $\mathrm{M}$ & 6.44 & 6.91 & 7.38 & 4.77 & 3.91 & 5.54 & 3.32 & 3.39 & 5.29 & 5.49 \\
\hline SD & 1.80 & 1.59 & 1.52 & 2.13 & 2.40 & 2.23 & 2.12 & 2.15 & 1.35 & 1.51 \\
\hline
\end{tabular}


SEEH, scales of attitude structure of volunteers; Coefficient alphas are presented in parentheses along the diagonal; ${ }^{a} p \leq 0.05$ (2-tailed); ${ }^{b} p \leq 0.01$ (2-tailed); ${ }^{c} p \leq 0.001$ (2-tailed).

The participants were grouped according to their immigrant status as follows: non-immigrants $(n=3025)$, people with immigrant background but with the German citizenship and no other (previous) citizenship $(n=183)$, and any other immigrants $(n=75)$. An ANOVA was conducted to investigate whether the two groups of immigrants differed with respect to their self-perceived integration.

\section{Results}

\section{Reasons for Volunteering}

As can be seen from Table 2, the most important motivating factors for doing volunteer work were social responsibility, self-experience and social ties, whereas social influence, career, and political responsibility seemed to be less important.

\section{Type of Organization}

No effects of type of organization on current reasons for volunteering were observed. Effect sizes (i.e. $\eta$ ) varied between 0.09 (SEEH self-experience subscale) and 0.01 (SEEH professional balance subscale).

\section{Gender}

On almost all SEEH scales, men and women had similar scores - with one exception: women scored higher on the SEEH self-experience subscale than men: $F(1,2694)=25.21, p<0.001, \eta=0.10$. Because there were differences among organizational samples with respect to gender (see Table 1), additional ANOVAs were conducted for each organizational sample separately. Within the VFB and GRC samples, no gender differences were detected with respect to the SEEH subscales. Within the THW sample, however, women scored higher on the SEEH self-experience subscale: $F(1,750)=11.98, p<0.01, \eta=0.13$.

\section{Age}

Age was associated with the following SEEH subscales: social ties $(r=-0.10, p<0.001)$, self-esteem $(r=-0.14$, $p<0.001)$, and career $(r=-0.32, p<0.001)$. Considering the number of years of voluntary service, the analysis led to approximately the same results as for age, with one exception: no association was detected between the number of years of service and the social ties subscale. A large significant effect of age on number of years of voluntary service was observed: $r=0.734, p<0.001$. The average starting age of volunteers was 20.8 years ( $\mathrm{SD}=8.5$, range: $6-67$ years). Of the 3320 studied volunteers, $11.4 \%$ ( $n=373 ; 1.5 \%$ missing values) had entered the voluntary service in the last 2 years. Of these 373 persons, $24.1 \%(n=90)$ were aged 19 or below, $57.6 \%(n=215)$ were aged between 20 and 39, 16.9\% (n=63) between 40 and 59, and only $1.3 \%(n=5)$ were aged 60 or over. Of the sample of volunteers up to 19 years of age, those who had entered the voluntary service within the last 2 years scored lower on the following SEEH subscales compared to those who had entered the service more than 2 years ago: self-experience $(F(1,148)=5.07, p<0.05, \eta=0.18)$, social responsibility $(F(1,147)=6.55, p<0.05$, $\eta=0.21)$, social influence $(F(1,146)=2.23, p=0.14, \eta=0.12)$, professional balance $(F(1,144)=8.12, p<0.01, \eta=0.23)$, career $(F(1,148)=5.02, p<0.05, \eta=0.18)$, and political responsibility $(F(1,144)=2.92, p=0.09, \eta=0.14)$. Accordingly, volunteers aged 19 or below who had entered the volunteer service in the last 2 years scored lower on the self-serving orientation scale $(F(1,140)=6.94, p<0.01, \eta=0.22)$ and the altruistic orientation scale $(F(1,144)=6.51$, $p<0.05, \eta=0.21$ ). No effects of time of service were detected for young adults (aged 20-39) and middle-aged adults (aged 40-59). No analysis was possible for the sample of volunteers aged 60 or over, because only five people had started the service in the last 2 years. 


\section{Immigration Background}

Of the 258 participants with an immigration background, 183 (71\%) had German citizenship and no other (previous) citizenship. Comparing the three different immigrant status groups (i.e. non-immigrants, immigrants with the German citizenship and no other (previous) citizenship, and immigrants), no effects on the SEEH subscales were detected. Effect sizes varied between $\eta=0.06$ (self-esteem) and $\eta=0.02$ (social responsibility and social ties). No differences were found between the two groups of immigrants with respect to their self-perceived integration in Germany. Both groups rated their self-perceived integration (from 1=not at all to 5=extremely) as very high $(\mathrm{M}=4.48, \mathrm{SD}=0.48$, and $\mathrm{M}=4.41, \mathrm{SD}=0.68$, respectively).

\section{Reasons for Termination a Volunteering Service}

To the question "How satisfied are you with your voluntary work?" (Likert scale: $1=$ very unsatisfied to 5=very satisfied), over $82 \%$ of the respondents answered to be satisfied or very satisfied with their voluntary work $(\mathrm{M}=3.96$, $\mathrm{SD}=0.81$, range: $1-5)$. However, $54.7 \%$ of the respondents had thought about ending their volunteer work (Table $3)$, the most important reasons for which were: difficulties with other volunteers/volunteer supervisor (17.9\%), lack of time $(15.0 \%)$, and difficulties regarding compatibility with professional commitments $(14.8 \%)$. Small effects of gender on reasons for termination were observed, as well as of age, and type of organization. No effect of immigrant status (yes/no) on reasons for termination was observed (see Table 3).

Table 3: "Have You Ever Thought about Ending your Volunteer Work in the Field of Crisis Management and Disaster Recovery?" ( $n=3320)$.

\begin{tabular}{|c|c|c|c|c|c|c|c|c|c|c|c|}
\hline & & \multirow[b]{2}{*}{ Total } & \multicolumn{3}{|c|}{ Organization $^{\mathrm{c}}$} & \multicolumn{2}{|c|}{ Gender $^{\mathrm{d}}$} & \multicolumn{2}{|c|}{ Migrant status $^{\mathrm{e}}$} & \multicolumn{2}{|c|}{ Age (years) } \\
\hline & & & VFB & GRC & THW & $\mathbf{M}$ & W & $\begin{array}{r}\text { Non- } \\
\mathbf{M}\end{array}$ & $\begin{array}{r}\text { Mi- } \\
\text { grant }\end{array}$ & & \\
\hline & $n^{\mathrm{a}}$ & $\%^{b}$ & $\%^{b}$ & $\%^{b}$ & $\%^{b}$ & $\%^{b}$ & $\%^{b}$ & $\%^{b}$ & $\%^{b}$ & $\mathbf{M}$ & SD \\
\hline No & 1495 & 45.3 & 50.3 & 43.5 & 43.7 & 54.5 & 43.8 & 45.4 & 45.1 & 34.40 & 12.57 \\
\hline $\begin{array}{l}\text { Yes, } \\
\text { own } \\
\text { ideas } \\
\text { could } \\
\text { not be } \\
\text { real- } \\
\text { ized }\end{array}$ & 88 & 2.7 & 2.2 & 2.3 & 3.3 & 2.1 & 2.8 & 2.7 & 3.1 & 34.88 & 11.01 \\
\hline $\begin{array}{l}\text { Yes, } \\
\text { own } \\
\text { finan- } \\
\text { cial } \\
\text { effort } \\
\text { too } \\
\text { great }\end{array}$ & 45 & 1.4 & 0.8 & 2.1 & 1.1 & 2.7 & 1.1 & 1.3 & 1.2 & 36.96 & 10.98 \\
\hline $\begin{array}{l}\text { Yes, } \\
\text { train- } \\
\text { ing } \\
\text { effort } \\
\text { too } \\
\text { large }\end{array}$ & 83 & 2.5 & 0.9 & 4.9 & 1.2 & 2.9 & 2.5 & 2.5 & 2.7 & 39.90 & 10.82 \\
\hline $\begin{array}{l}\text { Yes, } \\
\text { diffi- } \\
\text { culties } \\
\text { with } \\
\text { other } \\
\text { volun- } \\
\text { teers/vol- } \\
\text { unteer } \\
\text { super- } \\
\text { visor }\end{array}$ & 322 & 9.8 & 10.0 & 8.7 & 10.6 & 7.9 & 10.1 & 9.7 & 9.7 & 35.80 & 11.56 \\
\hline
\end{tabular}




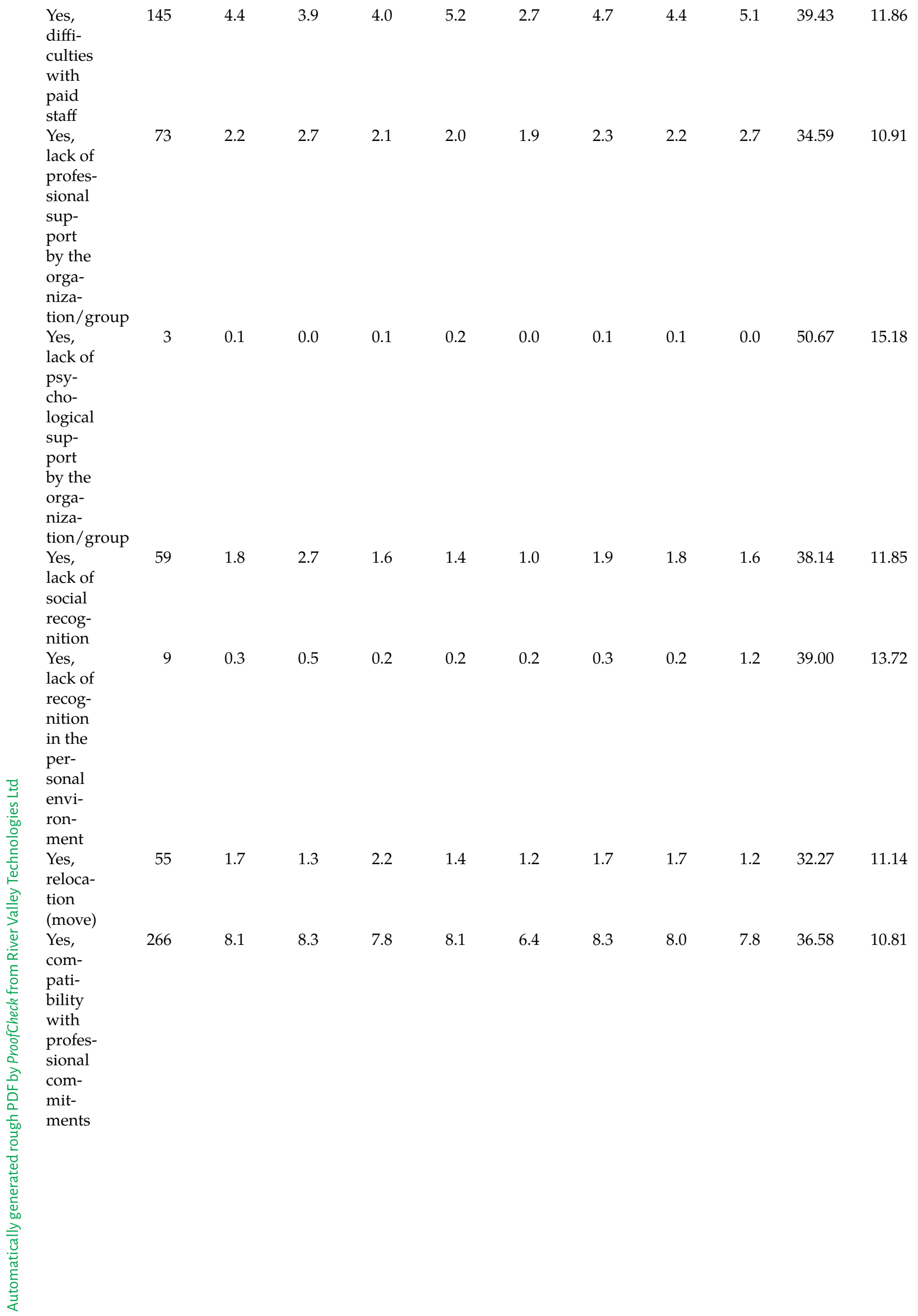




\begin{tabular}{|c|c|c|c|c|c|c|c|c|c|c|c|}
\hline $\begin{array}{l}\text { Yes, } \\
\text { com- } \\
\text { pati- } \\
\text { bility } \\
\text { with } \\
\text { family } \\
\text { re- } \\
\text { spon- } \\
\text { sibili- } \\
\text { ties }\end{array}$ & 158 & 4.8 & 4.5 & 5.0 & 4.8 & 5.0 & 4.8 & 4.9 & 3.9 & 38.77 & 8.60 \\
\hline $\begin{array}{l}\text { Yes, } \\
\text { lack of } \\
\text { time }\end{array}$ & 271 & 8.2 & 6.1 & 9.2 & 8.7 & 6.4 & 8.5 & 8.2 & 9.3 & 34.46 & 9.88 \\
\hline $\begin{array}{l}\text { Yes, } \\
\text { health } \\
\text { rea- } \\
\text { sons }\end{array}$ & 39 & 1.2 & 0.8 & 1.6 & 1.1 & 1.2 & 1.2 & 1.2 & 0.8 & 49.59 & 13.26 \\
\hline $\begin{array}{l}\text { Yes, } \\
\text { others }\end{array}$ & 187 & 5.7 & 5.0 & 4.7 & 7.1 & 3.9 & 6.0 & 5.8 & 4.7 & 38.71 & 12.30 \\
\hline
\end{tabular}

VFB, voluntary fire brigade; CRC, German Red Cross; THW, German federal agency for technical relief; $M$, men; W, women; ${ }^{a}$ Missing values: $n=22$ (0.7\%); ${ }^{b}$ valid percent, ${ }^{C}$ Cramer's V $=0.12, p<0.001$, Fisher Exact Test; ${ }^{\mathrm{d}}$ Cramer's V $=0.10, p<0.01$, Fisher Exact Test; ${ }^{\mathrm{e}}$ Cramer's V=0.06, $p=0.73$, Fisher Exact Test; ${ }^{\mathrm{f}} \mathrm{F}(15$, $3282)=9.30, p<0.001, \eta=0.20$.

\section{Discussion}

The present study has investigated people's motivations for volunteering in the field of civil protection, their demographic characteristics, and the role that the type of organization for which they provide their service plays. The first hypothesis predicted that the reasons for people doing voluntary service are similar for the different organizations considered here. This hypothesis was supported because no effects of type of organization on reasons for volunteering were detected.

Hypothesis 2, the expectation that some reasons for volunteering are similar for men and women (e.g. social motivation) and some dissimilar (e.g. to gain skills, experience, etc.), was also confirmed. In the present study, the reasons for men and women doing voluntary service were similar, with one exception: gaining skills and experience played a larger role for women than for men. Previous studies have found similar gender-related differences with respect to the self-experience/understanding motive ( Chapman and Morley 1999; Fletcher and Major 2004; Yadessa 2015). Findings regarding the relationships between gender and other reasons for volunteering are varied across different studies (see Chapman and Morley 1999; Switzer et al. 1999; Fletcher and Major 2004; Yadessa 2015). The diverging findings of previous studies could have arisen as a result of different volunteer samples (e.g. students, emergency service volunteers, etc.). What is important to note is that no effect sizes were reported in previous studies investigating the impact of gender on reasons for volunteering (see Chapman and Morley 1999; Switzer et al. 1999; Fletcher and Major 2004; Yadessa 2015). Interestingly, the present data further revealed that only in the THW sample, women reported a higher motivation to gain skills/self-experience; no gender differences were detected with respect to the motivation scales in the VFB and GRC samples. One explanation could be that the THW has specifically implemented 1:1 female mentoring programs to increase the proportion of women, and furthermore employs slogans such as "Technology is a matter of men? Not at the THW." ( German Federal Agency for Technical Relief [Technisches Hilfswerk] 2011). This strategy might enhance this aspect of women's motivation.

The third hypothesis, which predicted age to be negatively associated with career motivation and the motivation to gain knowledge and skills, was also shown to be correct, which is in line with previous research ( Omoto, Snyder, and Martino 2000; Okun and Schultz 2003). US statistics have shown that volunteers have a $27 \%$ higher chance of finding a job after being out of work than non-volunteers, possibly due the development of new skills and expansion of personal networks ( Cooperation for National and Community Service 2015). The current study also examined whether people entering a volunteer service have different reasons for volunteering than people who have already served for a longer time (Hypothesis 4). In the sample of volunteers aged 19 or below, six motives were less important for those who entered the service within the last 2 years than for volunteers who started more than 2 years ago: self-experience, social responsibility, social influence, professional balance, career, and political responsibility. Consequently, they scored lower on both the self-serving and the altruistic orientation dimension. This could be because young volunteers enter the service through their 
parents or friends, so they may have no explicit motives. In our study, of the volunteers who were aged 10 or below when they entered the service, $49.0 \%$ joined because of family members who were active members, and $45.1 \%$ were motivated by friends who were active members. Of those who were aged between 16 and 19 when they started, $30.7 \%$ joined because of family members, and $49 \%$ because of friends. In contrast, for young adults (aged 20-39) and middle-aged adults (aged 40-59), the time of entering the voluntary service (i.e. in the last 2 years vs. more than 2 years ago) did not have an effect on the self-serving and altruistic orientation dimension. No results were available for older adults (aged 60 or above), because very few of the older participants had entered the service in the last 2 years. Consequently, the fourth hypothesis is only partially supported.

Finally, the fifth hypothesis, which stated that reasons for volunteering in civil protection will be independent of immigrant status, was supported. As expected, the average level of self-perceived integration of the 258 immigrants was very high. The question how long they already lived in Germany was not asked, because immigrant status was assessed according to the Federal Statistical Office [Statistisches Bundesamt] (2015) in Germany (please see method section). Of the 258 immigrants, only 14 did not have the German citizenship.

In line with previous research in Germany ( Hielscher and Nock 2014), our sample indicates that an appreciable integration of females, older people, and immigrants - with regard to number of members - does not take place in civil protection organizations. In the field of civil protection, volunteering is more long-term and includes intensive training, continuous exercises and on-call services. For women, voluntary work is probably influenced by their life stages and possibly less stable than for men - presumably due to motherhood and family life. In the present study, women's main reasons for a potential termination of volunteering were the following two: too little time and difficulties with other volunteers/volunteer supervisors (Table 3). Furthermore, women may feel that they are discriminated in traditionally male-dominated organizations such as the VFB and THW ( Hielscher and Nock 2014).

Youth and young adults are the main resource for voluntary services. In the present study, $59.8 \%$ were aged 19 or below when they entered the service, $27.5 \%$ were aged $20-29,7.3 \%$ were aged $30-39$, and $5.3 \%$ were aged 40 or above. The average age of entry into the service was 21 years. Recently collected data of members of non-profit civil protection showed a similar age distribution: $58 \%$ were aged 20 or below when they entered the service, although a small increase of voluntary services of 13\% occurred at the age of 30-40 (13\%; BIK 2013). Janoski, Musick, and Wilson (1998) : p. 515 suggest that one way to recruit more young people into volunteering services is "...to ensure that lessons of civic duty and social obligations are learned early and well". They showed that volunteer work undertaken in high school has a strong positive influence on volunteering. In the present study, the sample of elderly volunteers was small and new members taking up voluntary service were the exception. An obvious reason is the age limit of 60 years of active service in the THW (before the year 2013) and of 60-67 years, depending on federal state, in the VFB ( German Federal Agency for Technical Relief [Technisches Hilfswerk] 2014; German Fire Service Association [Deutscher Feuerwehrverband] 2016a). However, although the GRC has no age limits specified, its share of volunteers aged 60 or above was also small (3.6\%). This raises the question of how the organizations can maintain their long-term volunteers. The main reasons for a potential termination indicated by seniors were difficulties with paid staff $(17.5 \%)$ and with other volunteers/volunteer supervisors (12.3\%). To investigate whether the current motives of senior volunteers are different from those when they started as a young person, longitudinal studies need to be conducted.

When interpreting the results of the present study, it is important to note that our sample is a convenience sample, which may therefore not be representative. For example, the percentage of female GRC volunteers was only about half of that in national GRC statistics (22.2\% vs. $41 \%$, respectively; Geenen 2012$)$, whereas the percentage of female THW (11.5\% vs. $13.0 \%)$ and VFB volunteers $(8.8 \%$ vs. $8.5 \%)$ was approximately the same as in the national organizational statistics ( German Federal Agency for Technical Relief [Technisches Hilfswerk] 2016a; German Fire Service Association [Deutscher Feuerwehrverband] 2016b). The percentage of immigrants volunteering in civil protection organizations was somewhat higher in our sample (7.9\%), in comparison with a representative study in Germany (2.1\%; BIK 2013). No official statistics are available on age structure in civil protection organizations, but, since this was an online study, the proportion of younger participants is expected to be higher.

Our findings have implications for practice and further research. This study has uncovered the various motives that drive people of different age groups to undertake voluntary service - these motives could be used in targeted recruitment advertising. Likewise, the finding that the motivation of women only differs from men's in one respect, namely that they value self-experience more than men, could also be used to recruit more women for voluntary service. Immigrant status played no role in our sample, which is most likely due the high level of integration of the volunteers with immigrant status. However, the low representation of immigrants in civil protection organizations suggests that a stronger intercultural orientation is necessary in order to promote volunteering by people with an immigrant background. Regarding targeted group recruitment strategies, another question is whether the target groups (women, immigrants and older people) could be gained as "new" volun- 
teers or whether already active volunteers are removed from other areas of voluntary service ( Hielscher and Nock 2014); future research is required in this respect.

\section{Acknowledgments}

The paper was written by some authors of the INKA group. The project INKA “Professional Integration of Volunteers in Disaster Response and Crisis Management" was funded by the Bundesministerium für Bildung und Forschung (BMBF; grant no 13N12196). The authors acknowledge the collaboration of their project partners: German Red Cross, National Network for Civil Society, Berliner Fire Department, Fraunhofer Institute of Labor Economics and Organization, and University of Stuttgart.

Conflict of interest: The authors declare that there are no conflicts of interest.

\section{References}

Alexander, D 2010. "The Voluntary Sector in Emergency Response and Civil Protection: Review and Recommendations." International Journal of Emergency Management 7 (2): 151-166. DOI:10.1504/IJEM.2010.033654.

Bierhoff, H.-W., T. Schülken, and M. Hoof. 2007. “Skalen der Einstellungsstruktur ehrenamtlicher Helfer $\langle$ Scales of Attitude Structure of Volunteers >." Zeitschrift für Personalpsychologie 6 (1): 12-27. DOI:10.1026/1617-6391.6.1.12.

BIK. 2013. Ergebnisbericht zur Durchführung einer repräsentativen CATI-Umfrage zum ehrenamtlichen Engagement im Zivil-und Katastrophenschutz [Report on the results of a representative CATI survey on volunteering in civil protection and disaster assistance]. Bundesamt für Bevölkerungsschutz und Katastrophenhilfe.

Chapman, J. G., and R. Morley. 1999. “Collegiate Service-Learning: Motives Underlying Volunteerism and Satisfaction with Volunteer Service." Journal of Prevention \& Intervention in the Community 18 (1-2): 19-33. DOI:10.1300/J005v18no1_03.

Clary, E. G., and M. Snyder. 1999. "The Motivations to Volunteer: Theoretical and Practical Considerations." Current Directions in Psychological Science 8 (5): 156-159.

Clary, E. G., M. Snyder, R. D. Ridge, P. Miene, and ] Haugen. 1994. "Matching Messages to Motives in Persuasion: A Functional Approach to Promoting Volunteerism." Journal of Applied Social Psychology 24 (13): 1129-1149. DOI:10.1111/j.1559-1816.1994.tbo1548.x.

Clary, E. G., M. Snyder, R. D. Ridge, J. Copeland, A. A. Stukas, J. Haugen, and P Miene. 1998. “Understanding and Assessing the Motivations of Volunteers: A Functional Approach." Journal of Personality and Social Psychology 74: 1516-1530. DOI:10.1037/0022-3514.74.6.1516.

Cooperation for National and Community Service. 2015. Overview Statistics https://www.nationalservice.gov/vcla/research .

Coppola, D. P 2015. Introduction to International Disaster Management. Amsterdam: Butterworth Heinemann.

Q3: Please update the Ref. “Dostál and Balarinová (2013)”Dostál, J., and L. Balarinová. 2013. “Volunteers in Emergency Management: An Investment in the Future?" Disaster Management and Human health Risk III 133: 381-391. DOI:10.2495/DMAN130341.

Federal Office of Civil Protection and Disaster Assistance [Bundesamt für Bevölkerungsschutz und Katastrophenhilfe]. 2015. Ehrenamt. Sicherung und Förderung des Ehrenamtes Volunteering [Volunteering. Assurance and promotion of voluntary work]. http://www.bbk.bund.de/DE/AufgabenundAusstattung/FoerderungEhrenamt/foerderungehrenamt_node.html .

Federal Statistical Office [Statistisches Bundesamt]. 2015. Bevölkerung und Erwerbstätigkeit. Bevölkerung mit Migrationshintergrund - Ergebnisse des Mikrozensus 2011 [Population and employment. Population with a migration background - results of the microcensus 2011]. https://www.destatis.de/DE/Publikationen/Thematisch/Bevoelkerung/MigrationIntegration/Migrationshintergrund2010220117004.pdf?_blob=publicationFile.

Federal Statistical Office [Statistisches Bundesamt]. 2016. Bevölkerung mit Migrationshintergrund aufRekordniveau [Population with migration background at record level]. https://www.destatis.de/DE/PresseService/Presse/Pressemitteilungen/2016/09/PD16_327_122.html;jsessionid=F1636780CoF84661BE20B51D3F4E6FC3.cae1.

Finkelstein, M. A 2009. "Intrinsic vs. Extrinsic Motivational Orientations and the Volunteer Process.” Personality and Individual Differences 46 (5-6): 653-658. DOI:10.1016/j.paid.2009.01.010.

Fletcher, T. D., and D. A. Major. 2004. “Medical Students' Motivations to Volunteer: An Examination of the Nature of Cender Differences." Sex Roles 51 (1-2): 109-114. DOI:10.1023/B:SERS.0000032319.78926.54.

Francis, J., and M. Jones. 2012. "Emergency Service Volunteers: A Comparison of Age, Motives and Values." The Australian Journal of Emergency Management 27 (4): 23-28.

Frisch, M. B., and M. Cerrard. 1981. "Natural Helping Systems: A Survey of Red Cross Volunteers.” American Journal of Community Psychology 9 (5): 567-579. DOI:10.1007/BFoo896477. 
Geenen, E. M 2012. Frauen als Zielgruppe ehrenamtlichen Engagements im Zivil-und Katastrophenschutz. Kurzgutachten im Auftrag des Bundesamtes für Bevölkerungsschutz und Katastrophenhilfe [Women as a target group of voluntary commitment to civil and disaster protection. Short report on behalf of the Federal Office ofCivil Protection and Disaster]. http://www.b-b-e.de/fileadmin/inhalte/themen_materialien/rettungsdienste/Zielgruppe_Frauen.pdf.

German Federal Agency for Technical Relief [Technisches Hilfswerk]. 2011. Das könnt ihr auch! [You can!] https://www.thw.de/SharedDocs/Meldungen/DE/Meldungen/national/2011/02/meldung_003_mentorinnen_projekt.html .

German Federal Agency for Technical Relief [Technisches Hilfswerk]. 2014. Bundesausschuss: Altersbeschränkung wird aufgehoben [Federal committee: age restriction annulled] https://www.thw.de/SharedDocs/Meldungen/DE/Veranstaltungen/national/2013/04/meldung_002_bundesausschuss.html?nn=922620.

German Federal Agency for Technical Relief [Technisches Hilfswerk]. 2016a. Mehr Frauen im THW [More woman in THW] https://www.thw.de/SharedDocs/Meldungen/DE/Veranstaltungen/national/2016/04/meldung_002_tagung_frauen_im_thw.html?nn=923314.

German Federal Agency for Technical Relief [Technisches Hilfswerk]. 2016b. Mitmachen und Unterstützen [Join and support] https://www.thw.de/DE/THW/thw_node.html .

German Fire Service Association [Deutscher Feuerwehrverband]. 2016a. Altersgrenzen bei der Feuerwehr [Age limits at the fire brigade] http://www.feuerwehrverband.de/fileadmin/Inhalt/FACHARBEIT/FB7_Sozialwesen/2016_03_DFV-Informationen_Altersgrenzen_JF_FF_BF_WF.pdf.

Cerman Fire Service Association [Deutscher Feuerwehrverband]. 2016b. Feuerwehrstatistik [fire service statistics] http://www.feuerwehrverband.de/statistik.html.

German Red Cross [Deutsches Rotes Kreuz]. 2016. Der Mensch im Mittelpunkt-Ehrenamt beim DRK [People at the center-Volunteering at the GRC] https://www.drk.de/mitwirken/der-mensch-im-mittelpunkt-ehrenamt-beim-drk/.

Ha, K.-M., and J.-Y. Ahn. 2008. "National Emergency Management System: The United States and Korea." Journal of Emergency Management 6 (1): 31-44. DOI:10.5055/jem.2010.0020.

Haddow, G. D., J. A. Bullock, and D. P. Coppola. 2014. Introduction to Emergency Management., 5th ed. Amsterdam: Butterworth-Heinemann

Handy, F., and I. Greenspan. 2009. “Immigrant Volunteering: A Stepping Stone to Integration?” Nonprofit and Voluntary Sector Quarterly 38 (6): 956-982. DOI:10.1177/0899764008324455.

Hielscher, V., and L. Nock. 2014. “Perspektiven des Ehrenamtes im Zivil- und Katastrophenschutz. Metaanalyse und Handlungsempfehlungen 〈Perspectives of volunteering in civil protection. Meta-analysis and recommendations for action〉." In Iso-Report. Berichte aus Forschung und Praxis [Iso-Repor. Reports from research and practice]. Saarbrücken: Institut für Sozialforschung und Sozialwirtschaft (iso) e.V.

Hwang, W 2006. “Acculturative Family Distancing: Theory, Research, and Clinical Practice." Psychotherapy: Theory, Research, Practice, Training 43 (4): 397-409. DOI:10.1037/0033-3204.43.4.397..

Janoski, T., M. Musick, and J. Wilson. 1998. “Being Volunteered? The Impact of Social Participation and Pro-Social Attitudes on Volunteering." Sociological Forum 13 (3): 495-519. DOI:10.1023/A:1022131525828.

Klöpper, M 2012. Rückgang: THW verliert rund 2.000 Helfer [Decline: THW loses around 2,000 helpers]. http://www.feuerwehrmagazin.de/nachrichten/news/ruckgang-thw-verliert-rund-2-000-helfer-29045.

Mai, R., and F. Swiaczny. 2008. Demographische Entwicklung - Potenziale für bürgerschaftliches Engagement: Bericht des Bundesinstituts für Bevölkerungsforschung [Demographic development - Potential for voluntary civil involvement: Report of the Federal Institute for Population Research]. Wiesbaden: Bundesinstitut für Bevölkerungsforschung [Federal Institute for Population Research].

Okun, M. A., and A. Schultz. 2003. "Age and Motives for Volunteering: Testing Hypotheses Derived from Socioemotional Selectivity Theory." Psychology and Aging 18: 231-239. DOI:10.1037/0882-7974.18.2.231.

Omoto, A. M., M. Snyder, and S. C. Martino. 2000. "Volunteerism and the Life Course: Investigating Age-Related Agendas for Action." Basic and Applied Social Psychology 22 (3): 181-197. DOI:10.1207/15324830051036081.

Sakamoto, M 2012. “The Rise of NCOs/NPOs in Emergency Relief in the Great East Japam Earthquake." Japan Social Innovation Journal 2 (1): 26-35. DOI:10.12668/jsij.2.26.

Schiefer, David 2013. "Cultural Values and Group-Related Attitudes: A Comparison of Individuals with and without Migration Background Across 24 Countries." Journal of Cross-Cultural Psychology 44 (2): 245-262. DOI:10.1177/0022022112444898.

Shanli, H 2014. China's NCOs Essential to Disaster Preparedness. http://asiafoundation.org/2014/01/08/chinas-ngos-essential-to-disasterpreparedness/.

Statista CmbH. 2016. Anzahl der Mitglieder und Verbände des Deutschen Rotes Kreuzes (DRK) von 2009 bis 2015 [Number of members and associations of the Cerman Red Cross (DRC) from 2009 to 2015] https://de.statista.com/statistik/daten/studie/36979/umfrage/anzahl-der-mitgliederund-verbaende-des-drk/.

Switzer, C. L., C. E. Switzer, A. A. Stukas, and C. E Baker. 1999. “Medical Student Volunteer: Cender Differences and Comparisons to other Volunteers." Journal of Prevention \& Intervention in the Community 18 (1-2): 53-64. DOI:10.1300/J005v18no1_05.

Widjaja, E 2010. Motivation Behind Volunteerism. (Bachelor of Arts), Claremont McKenna College. Retrieved from http://scholarship.claremont.edu/cmc theses/4.

Work Group of the German Market and Social Research Institute e.V., Work Group of the Association of Social Science Institutes e.V., Association of Cerman Market and Social Researchers e.V., German Society for Online e.V [Arbeitskreis Deutscher Markt - und Sozialforschungsinstitute e.V., Arbeitsgemeinschaft Sozialwissenschaftlicher Institute e.V., Berufsverband Deutscher Markt- und Sozialforscher e.V., Deutsche Gesellschaft für Online-Forschung e.V. 2006. Richtlinie für die Befragung von Minderiährigen [Guideline for Interviewing Minors] http://bvm.org/fileadmin/pdf/Recht_Berufskodizes/Richtlinien/RL_2006_Minderjaehriger_D.pdf.

Yadessa, T 2015. Motivational Factors among Volunteers: The case of Rotaract Clubs in Addis Ababa. (Masters in Social Psychology), Addis Ababa University. http://etd.aau.edu.et/bitstream/123456789/7562/1/7.\%20Tsige\%20Yadessa.pdf . 